\title{
Assessment and comparison of phytochemical constituents and biological activities of bitter bean (Parkia speciosa Hassk.) collected from different locations in Malaysia
}

\author{
Ali Ghasemzadeh ${ }^{1 *}\left(\mathbb{0}\right.$, Hawa Z. E. Jaafar ${ }^{1}$, Mohamad Fhaizal Mohamad Bukhori ${ }^{1,2}$, Mohd Hafizad Rahmat ${ }^{1}$ \\ and Asmah Rahmat ${ }^{3}$
}

\begin{abstract}
Background: Parkia speciosa seeds are a common ingredient in Malay cuisine with traditional interest because of its medicinal importance and content of health-promoting phytochemicals. This study evaluated the phytochemical constituents and biological activities (antioxidant and antibacterial activities) of Parkia speciosa Hassk seeds collected from three different regions of Malaysia (Perak, Negeri Sembilan and Johor). Phytochemical constituents (total flavonoid and total phenolic) were measured using the spectrophotometric method, and individual flavonoids and phenolic acids were identified using ultra-high-performance liquid chromatography. Ferric reducing antioxidant potential (FRAP) assay and 2,2-diphenyl-1-picrylhydrazyl (DPPH) assay we used in order to evaluation of antioxidant activities. Disc diffusion method was employed for the evaluation of antibacterial activity of extracts against Gram-positive and Gram-negative bacterial strains.
\end{abstract}

Results: The primary screening of phytochemicals showed that P. speciosa seeds contain alkaloids, terpenoids, flavonoids, and phenolics. Samples collected from Perak contained the highest levels of the phytochemical constituents, with highest DPPH and FRAP activity followed by Negeri sembilan and Johor. From the identified compounds, quercetin and gallic acid were identified as the most abundant compounds. Seeds collected from the Perak location exhibited potent antibacterial activity, against both Gram-positive and Gram-negative bacteria strains. Staphylococcus aureus and Bacillus subtilis were recorded as the bacterial strains most sensitive to P. speciosa seed extracts. Correlation analysis showed that flavonoid compounds are responsible for the antioxidant activities of the P. speciosa seeds studied, while antibacterial activity showed a high correlation with the levels of gallic acid.

Conclusions: Parkia speciosa seed grown in Perak exhibit the highest concentrations of phytochemicals, as well as the highest biological activity. It may also be recommended for the food industry to use seeds from this area for their products, which are going to compete in the expanding functional food markets.

Keywords: Parkia speciosa Hassk, Phytochemicals, DPPH assay, FRAP assay, Antibacterial activity

\section{Background}

Plants present a virtually endless supply of potential cures for humanity. Historically, they have formed the

\footnotetext{
*Correspondence: alighasemzadeh@upm.edu.my

1 Department of Crop Science, Faculty of Agriculture, Universiti Putra Malaysia, 43400 Serdang, Selangor, Malaysia

Full list of author information is available at the end of the article
}

oldest basis for developing medicines used to relieve human suffering and treat many debilitating diseases [1]. A plant can be compared to a chemical factory where a wide range of organic substances is manufactured. Novel bioactive phytochemicals are important feedstock for potential development of new pharmaceuticals and the rich biodiversity of the tropical forest holds great promise for the discovery of such compounds [2]. A major 
objective of natural product research is the preclinical development of bioactive natural products and their analogues [3]. The production of phytochemicals varies not only between varieties or species but also depends on external variables such as environmental conditions, agricultural practices, and post-harvest handling. Therefore, the phytochemical composition of a given variety/ species of plant can vary according to geographic region and this difference can be attributed to geographic differences in type of soil, levels of precipitation, light intensity, humidity, etc. $[4,5]$.

Parkia speciosa Hassk, from the Fabaceae family is a southeast Asian legume. It is locally known in Malaysia as "Patai, Petai" and is generally called "Bitter bean" in English [6]. This plant grows naturally in low land tropical forests and is cultivated in Malaysian villages. The tree grows to a height of $15-40 \mathrm{~m}$, bearing flat, edible bean pods with bright green, plump, almond-shaped seeds [7]. The seeds are flattened and elliptical in shape with a nutty and firm texture. P. speciosa seeds are a common ingredient in Malay cuisine and are frequently served beside sambal, dried shrimp, and chili pepper as a popular local delicacy. Several phytochemicals such as flavonoids, phenolics, terpenoids, and fatty acids have been reported in seed extracts of P. speciosa [8-11]. In traditional medicine, the seeds of $P$. speciosa are pounded and boiled to be used for alleviating stomach pain and have been considered beneficial in treating liver disease, diabetes, and worm infestations. Besides the culinary uses of P. speciosa seed, evidence of anticancer activity [12], antioxidant activity [13], antibacterial activity [14] as well as antiangiogenic activity [13] has been reported by previous studies. Phytochemicals in plants are responsible for their biological activities [4]. Typically, such compounds are produced and accumulate at various levels in plant tissues. Their production strongly correlates to the growing climate, agricultural practices, specific vegetative stages, and other environmental variables [15-17]. Results of previous studies have shown that the production of phytochemicals and the biological activity of the same variety/species of plant can be different when sampling was done from different areas [17]. Therefore, to produce plants with higher phytochemical quality and biological activity it is necessary to optimize the plantation or sampling process. The identification of suitable plantation sites can thus be very important. In Malaysia, it is reported that phytochemical constituents and biological activities of some herbs like as Murraya koenigii and Pandanus amaryllifolius when sampling was done from different areas $[16,18]$. The primary objective of this study was the evaluation and comparison of phytochemical constituents (flavonoids and phenolic acids) and antioxidant and antimicrobial activities of $P$. speciosa extracts from seeds collected in three different plantation sites in the northern, central and southern regions of Malaysia. The correlation between the identified compounds and the biological activity of $P$. speciosa seed extract was also examined.

\section{Methods}

Pod of P. speciosa was harvested (at the same time of year in all three regions) from three different locations of Malaysia: Perak in northern Malaysia, Negeri Sembilan in central Malaysia and Johor in southern Malaysia. After cleaning and washing with tap water, the seeds were removed from the pods. Seeds were dried in an oven at temperature of $45^{\circ} \mathrm{C}$ for $120 \mathrm{~h}$ (5 days). Dried seeds were ground with miller (mesh size 80 ). Seed powders were kept refrigerated at the temperature of $4-5{ }^{\circ} \mathrm{C}$ for future analysis. Samples were submitted to Institute of Bio-science (IBS), Universiti Putra Malaysia and identified as $P$. speciosa Hassk and voucher specimens were deposited at herbarium of IBS.

\section{Extraction}

Five gram of dried seed powder from each sample was transferred to a round-bottom flask. Absolute ethanol $(25 \mathrm{~mL})$ was added and the mixture was shaken gently with a shaker at $80 \mathrm{rpm}$ for $10 \mathrm{~min}$. The mixture was then refluxed for $1 \mathrm{~h}$, cooled at room temperature, and filtered using Whatman filter paper No. 1. The solvent was evaporated using a rotary evaporator, and the residue was kept at $-20^{\circ} \mathrm{C}$ for future analysis.

\section{Preliminary screening for phytochemicals}

Extracts of $P$. speciosa seeds were subjected to a number of preliminary phytochemical screening tests, as described below. To establish the presence of hydrolyzable tannins, ethanol extracts were treated with a $15 \%$ ferric chloride test solution and the resultant color was noted. Blue colour indicated the presence of hydrolyzable tannins. For alkaloid screening, $2 \mathrm{~g}$ of each extract were dissolved in $4 \mathrm{~mL}$ of ethanol containing 3\% tartaric acid. Each test sample was then divided into three test tubes, and tested using Hager's reagent, Mayer's reagent, and Marquis reagent. Precipitation in any of the three test tubes indicated the presence of alkaloids. For flavonoid screening, $5 \mathrm{~mL}$ of $\mathrm{NaOH}(20 \%)$ were added to each sample of ethanol extract; yellow colour indicated the presence of flavonoids. For phenolic screening, $4 \mathrm{~mL}$ of each extract was mixed with water and transferred to a water bath at the temperature of $45^{\circ} \mathrm{C}$. Then, $4 \mathrm{~mL}$ of $\mathrm{FeCl}_{3}(3 \%)$ was added. Green or blue colour indicated the presence of phenolic compounds. For saponin screening, $2.5 \mathrm{~g}$ of seed powder was extracted with hot water. Then it was cooled to room temperature, shaken vigorously 
and allowed to stand for $20 \mathrm{~min}$. Froth thickness of more than $1.2 \mathrm{~cm}$ indicated the presence of saponins. For terpenoid screening, $1 \mathrm{~g}$ of extract was dissolved in $4 \mathrm{~mL}$ of chloroform, after which $3 \mathrm{~mL} \mathrm{H}_{2} \mathrm{SO}_{4}$ was added. Reddish-brown indicated the presence of terpenoids [19-21].

\section{Total flavonoid content (TFC)}

Crude extracts $(5.0 \mathrm{mg})$ of seeds collected from each of the three locations were dissolved in absolute ethanol $(10 \mathrm{~mL})$. For each sample, $5 \mathrm{~mL}$ of the resulting solution was mixed with $5 \mathrm{~mL}$ of aluminum trichloride solution (2\%). Solution was incubated for $10 \mathrm{~min}$ in darkness. The absorbance of the solutions was read at $415 \mathrm{~nm}$ using a spectrophotometer. For the calibration curve $\left(R^{2}=995\right)$, the absorbance of different concentrations of quercetin (CAS Number 6151-25-3, Sigma-Aldrich, Shah Alam, Malaysia) was read and the final TFC was expressed in milligram quercetin equivalent $(\mathrm{QE})$ per gram dry material (DM) [22, 23].

\section{Total phenolic content (TPC)}

Crude extracts $(5.0 \mathrm{mg})$ of seeds collected from each the three sites were dissolved in ethanol (20 mL each). Afterward, $400 \mu \mathrm{L}$ of this solution was diluted with $40 \mathrm{~mL}$ of distilled water followed by adding $2 \mathrm{~mL}$ of Folin-Ciocalteu reagent (tenfold dilution). The mixture was then shaken well and incubated for $10 \mathrm{~min}$ in the dark. After incubation, $2 \mathrm{~mL}$ of sodium carbonate (7.5\%) were added to each sample and the samples were incubated again for $30 \mathrm{~min}$. The absorbance of the samples was read at $765 \mathrm{~nm}$ using a spectrophotometer. For the calibration curve $\left(R^{2}=991\right)$, the absorbance of different concentrations of gallic acid (CAS Number 5995-86-8, Sigma-Aldrich, Malaysia)was read and the final TPC was expressed in milligram gallic acid equivalent (GAE) per gram DM [23, 24].

\section{Identification of individual flavonoids and phenolic acids using UHPLC}

Individual flavornoids and phenolic acids were identified using ultra-high-pressure liquid chromatography (UHPLC) with the following specifications: mobile phases were (A) ortho-phosphoric acid 0.03 M, (B) Methanol HPLC grade; Column: C18 $(5 \mu \mathrm{m}, 4.6 \times 250 \mathrm{~mm}$; ZORBAX Eclipse Plus C18), injection volume: $10 \mu \mathrm{L}$, flow rate: $1 \mathrm{~mL} \mathrm{~min}{ }^{-1}$, column temperature $35{ }^{\circ} \mathrm{C}$ with detector wavelength of 280,320 , and $360 \mathrm{~nm}$. The gradient mode was used as follows: $0 \mathrm{~min} 4.0 \% \mathrm{~B}, 10 \mathrm{~min}$ $100 \% \mathrm{~B}, 15 \mathrm{~min} 100 \% \mathrm{~B}$, and $2.0 \mathrm{~min} 4.0 \% \mathrm{~B}$. The injection of each sample and the standards was done in triplicate. The identification of each compound was done by comparing the retention times with standards, UV spectra and UV absorbance ratios after co-injection of samples and standards. All standards were purchase from SigmaAldrich (Malaysia).

\section{Antioxidant analysis 2,2-Diphenyl-1-picrylhydrazyl (DPPH) assay}

About $6 \mathrm{~mL}$ of each seed extract was dissolved in $6 \mathrm{~mL}$ of methanolic solution of DPPH $(100 \mu \mathrm{M})$. The mixture was incubated at $37{ }^{\circ} \mathrm{C}$ for $20 \mathrm{~min}$ in the dark. The absorbance of the resulting solutions was read at $5.17 \mathrm{~nm}$ using a spectrophotometer [22]. $\alpha$-Tocopherol and butylated hydroxytoluene (BHT) were used as positive controls. The percentage of DPPH activity was calculated as follows:

$\%$ inhibition $=[($ absorbance of control - absorbance of sample $) /$ absorbance of control] $\times 100$.

\section{Ferric reducing antioxidant potential (FRAP) assay}

FRAP reagent was prepared fresh as follows: $\mathrm{FeCl}_{3}$ $(5 \mathrm{~mL}), 2,4,6$-tripyridyl- $S$-triazine $(5 \mathrm{~mL})$, acetate buffer $\left(50 \mathrm{~mL}, \mathrm{pH} 3.6,0.3 \mathrm{M} \mathrm{L}^{-1}\right)$. The mixture was incubated in a water bath $\left(37^{\circ} \mathrm{C}\right)$ for $20 \mathrm{~min}$ in the dark. $1 \mathrm{~mL}$ of seed extract was dissolved in $10 \mathrm{~mL}$ of FRAP reagent and incubated in a water bath at $26^{\circ} \mathrm{C}$ for $30 \mathrm{~min}$ in the dark. The absorbance of the solutions was read at $5.93 \mathrm{~nm}$ using a spectrophotometer. Acetate buffer was used as the blank. For the standard curve preparation, $\mathrm{FeSO}_{4} \cdot 7 \mathrm{H}_{2} \mathrm{O}$ with concentrations ranging from $100 \mathrm{mM}$ to $1000 \mathrm{mM}$ was used. The results were expressed in $\mu \mathrm{M}$ of $\mathrm{Fe}(\mathrm{II}) \mathrm{g}^{-1} \mathrm{DM}$ [25].

\section{Antimicrobial assay}

Antibacterial activity of $P$. speciosa seed extracts against Gram-positive and Gram-negative bacteria strains was evaluated using the disc diffusion method. For each sample, $100 \mathrm{mg}$ of crude extract were dissolved in $10 \mathrm{~mL}$ of dimethyl sulfoxide (DMSO). Mueller-Hinton agar medium was prepared in Petridishes $(15 \mathrm{~mL})$ and sterilized by autoclaving at $120 \pm 2{ }^{\circ} \mathrm{C}$ for $20 \mathrm{~min}$. After inoculation, the Petri dishes were dried for $15 \mathrm{~min}$. Wells of $6 \mathrm{~mm}$ diameter were punched off with a sterile Pasteur pipette and filled with seed extracts $(80 \mu \mathrm{L})$. The plates were incubated at $37 \pm 2{ }^{\circ} \mathrm{C}$ for $24 \mathrm{~h}$. Gentamicin and ciprofloxacin at the concentration of $5 \mu \mathrm{g} \mathrm{mL} \mathrm{m}^{-1}$ were used as a positive control and 10\% DMSO was used as a negative control. The zone of inhibition that appeared after $24 \mathrm{~h}$ was measured (in $\mathrm{mm}$ ) as a property of the extract antibacterial activity.

\section{Evaluation of minimum inhibitory concentration (MIC)}

The minimum inhibitory concentration (MIC) of seed extracts was measured by micro dilution assay. A series of diluted extracts (ranging from 20 to $100 \mu \mathrm{g} \mathrm{mL}^{-1}$ ) were prepared in sterile 96-well micro plates using 
Mueller-Hinton broth. Bacterial suspension $(50 \mu \mathrm{L})$ was mixed with an equal volume of each dilution. The blank $(150 \mu \mathrm{L}$ broth) and the bacteria $(100 \mu \mathrm{L}$ broth and $50 \mu \mathrm{L}$ bacteria suspension) were prepared and gentamicin and ciprofloxacin were used as positive controls. The plates were incubated for $24 \mathrm{~h}$ at $37{ }^{\circ} \mathrm{C}$. The diameter of the clear area (in $\mathrm{mm}$ ) was measured directly on the dishes. The MIC was determined by selecting the lowest concentration (highest dilution) of seed extract that showed no growth of the bacteria strains after $24 \mathrm{~h}$. Three replicates were used for each concentration of the extract (Table 1).

\section{Results and discussion}

\section{Preliminary phytochemical screening}

The results of the primary phytochemical screening of $P$. speciosa seeds collected from different locations in Malaysia are shown in Table 2. Ethanol extracts of $P$. speciosa seeds collected from Perak, Negeri Sembilan and Johor all contained alkaloids, terpenoids, phenolics, and flavonoids. Saponins and tannins were not observed in any of the $P$. speciosa seed extracts. The presence of phytochemicals in herbs and crops is strongly dependent on the extraction method and solvent type used. These results are consistent with previous studies which showed that chloroform extracts of $P$. speciosa seeds contain terpenoids (e.g., $\beta$-sitosterol and stigmasterol) and cyclic polysulfides, namely, hexathionine, tetrathiane, trithiolane, pentathiopane, and pentathiocane [26]. Water and ethanol extracts of $P$. speciosa seeds have also been found previously to contain phenolics (gallic acid) and flavonoids $[8,9]$.

\section{Total flavonoid and individual flavonoid content}

Total flavonoid and individual flavonoid content of seed extracts of $P$. speciosa was measured. As depicted in Table 3, TFC varied significantly between the sampled locations. Perak represents the highest TFC (12.4 mg QE $\mathrm{g}^{-1} \mathrm{DM}$ ), followed by Negeri Sembilan (9.2 $\mathrm{mg} \mathrm{QE} \mathrm{g}^{-1}$ $\mathrm{DM}$ ) and Johor (7.4 $\left.\mathrm{mg} \mathrm{QE} \mathrm{g}^{-1} \mathrm{DM}\right)$. Six distinct flavonoid compounds (quercetin, rutin, kaempferol, catechin, luteolin, and myricetin) were identified from P. speciosa seed extracts. High concentrations of quercetin, kaempferol, catechin, luteolin, and myricetin were observed in extracts of seeds harvested in the Perak location.

Table 1 Climatic and geographical information of sampling area

\begin{tabular}{|c|c|c|c|c|c|c|c|}
\hline Locations & $\begin{array}{l}\text { Lowest tem- } \\
\text { perature }\left({ }^{\circ} \mathrm{C}\right)\end{array}$ & $\begin{array}{l}\text { Highest tem- } \\
\text { perature }\left({ }^{\circ} \mathrm{C}\right)\end{array}$ & $\begin{array}{l}\text { Above sea level } \\
\text { (m) }\end{array}$ & $\begin{array}{l}\text { Average } \\
\text { humidity (\%) }\end{array}$ & $\begin{array}{l}\text { Average light } \\
\text { intensity } \\
\left(\mu \mathrm{mol} \mathrm{m} \mathrm{m}^{-2} \mathrm{~s}^{-1}\right)\end{array}$ & $\begin{array}{l}\text { Average sunny } \\
\text { day (h) }\end{array}$ & $\begin{array}{l}\text { Average rainfall } \\
(\mathrm{mm})\end{array}$ \\
\hline Perak & 21 & 36 & 45 & 84 & 1020 & 140 & 224 \\
\hline Negeri Sembilan & 22 & 37 & 34 & 80 & 940 & 181 & 195 \\
\hline Johor & 23 & 36 & 32 & 78 & 860 & 166 & 181 \\
\hline
\end{tabular}

Table 2 Primary screening of phytochemicals from ethanol extract of $P$. speciosa seed

\begin{tabular}{|c|c|c|c|c|c|c|}
\hline Locations & Alkaloids & Saponins & Terpenoids & Phenolics & Flavonoids & Tannins \\
\hline Perak & + & - & + & + & + & - \\
\hline Negeri Sembilan & + & - & + & + & + & - \\
\hline Johor & + & - & + & + & + & - \\
\hline
\end{tabular}

+ and - represent presence and absence of compound

Table 3 Total flavonoid content and some separated flavonoid compounds from ethanol extract of $P$. speciosa seed collected from different locations of Malaysia

\begin{tabular}{|c|c|c|c|c|c|c|c|}
\hline Locations & Total flavonoids & Quercetin & Rutin & Kaempferol & Catechin & Luteolin & Myricetin \\
\hline Perak & $12.4 \pm 3.51^{\mathrm{a}}$ & $2.71 \pm 0.69^{a}$ & $1.80 \pm 0.29^{a}$ & $0.66 \pm 0.09^{a}$ & $1.48 \pm 0.59^{\mathrm{a}}$ & $1.00 \pm 0.19^{a}$ & $0.76 \pm 0.22^{a}$ \\
\hline Negeri Sembilan & $9.2 \pm 1.49^{b}$ & $2.15 \pm 0.49^{a}$ & $1.91 \pm 0.38^{a}$ & $0.42 \pm 0.04^{b}$ & $1.15 \pm 0.24^{\mathrm{a}}$ & $0.66 \pm 0.05^{b}$ & $0.27 \pm 0.02^{c}$ \\
\hline Johor & $7.4 \pm 1.88^{c}$ & $1.47 \pm 0.38^{b}$ & ND & ND & $0.90 \pm 0.33^{b}$ & $0.49 \pm 0.01^{c}$ & $0.42 \pm 0.03^{b}$ \\
\hline
\end{tabular}

Data are means of triplicate measurements \pm standard deviation. Means not sharing a common single letter in each column for each measurement were significantly different at $P<0.05$. The units of total flavonoids and flavonoid compounds are mg quercetin equivalents per gram DM and $\mathrm{mg}$ per gram DM

ND not detected 
The highest content of rutin was registered at the Negeri Sembilan location. Extracts from the Johor location had low concentrations of all flavonoid compounds, and rutin and kaempferol were not detected in the Johor samples. Several factors influence flavonoid synthesis in herbs and crops, such as environmental conditions (light intensity, $\mathrm{CO}_{2}$ concentration, temperature) [27-30], and agricultural practices (fertilizer, irrigation, harvesting, post-harvesting) [31-34]. Wang and Zheng [35] showed that content of flavonoids, phenolics and anthocyanin of strawberry decreased significantly with decreasing of day and night temperature. In a study, Gliszcynska-Swiglo et al. [36] reported a positive and significant correlation between flavonoids content of broccoli and total solar radiation during growth period. Location of plantation was highlighted as a major environmental factor for quercetin content of onion [37]. The differences that this study has found between the sampled locations in TFC and individual flavonoid compounds could be related to environmental conditions such as light intensity, precipitation and temperature levels, and geographical differences. Table 4 show linearity and regression equation of the flavonoid and phenolic compounds.

\section{Total phenolic and individual phenolic acid content}

Total phenolic and individual phenolic acid content from seed extracts of $P$. speciosa was measured. As demonstrated in Table 5, TPC was significantly influenced by sampling location. The highest TPC was recorded at Perak (26.3 $\mathrm{mg} \mathrm{GAE} \mathrm{g}^{-1} \mathrm{DM}$ ) followed by Negeri Sembilan (20.5 $\mathrm{mg} \mathrm{GAE} \mathrm{g}^{-1} \mathrm{DM}$ ) and Johor (14.9 mg GAE $\left.\mathrm{g}^{-1} \mathrm{DM}\right)$. Five phenolic acids (gallic acid, caffeic acid, ferulic acid, trans-cinnamic acid, and $p$-coumaric acid) were identified. In a result similar to that of the flavonoid assay, Perak had the highest concentration of phenolic acids followed by Negeri Sembilan and Johor. Caffeic acid was not detected in the seed extracts from Negeri Sembilan, and no significant difference was observed between Perak and Johor samples in caffeic acid content. Ferulic acid and $p$-coumaric acid were not detected in the Johor samples either

\section{Antioxidant activity}

Ethanol extracts of $P$. speciosa seed collected from the three locations were evaluated for antioxidant activity using DPPH and FRAP assays. As shown in Table 6, $\mathrm{DPPH}$ free radical scavenging activity of extracts was

Table 4 Linearity and regression equation of the flavonoid and phenolic compounds

\begin{tabular}{|c|c|c|c|c|c|c|}
\hline Compounds & $U V\left(\lambda_{\max }\right)$ & $R_{t}(\min )$ & Linear regresion & $\mathrm{R}^{2}$ & $\operatorname{LOD}\left(\mu \mathrm{g} \mathrm{mL}^{-1}\right)$ & $\mathrm{LOQ}\left(\mu \mathrm{g} \mathrm{mL}^{-1}\right)$ \\
\hline Quercetin & 355 & 10.2 & $y=92.846 x+37.26$ & 0.9991 & 0.91 & 3.02 \\
\hline Rutin & 260 & 4.8 & $y=86.437 x+22.71$ & 0.9984 & 1.20 & 3.98 \\
\hline Kaempferol & 275 & 18.7 & $y=146.209 x+30.61$ & 0.9947 & 0.67 & 2.24 \\
\hline Catechin & 280 & 3.9 & $y=452.017 x+62.19$ & 0.9996 & 0.16 & 0.53 \\
\hline Luteolin & 275 & 14.5 & $y=265.733 x+46.52$ & 0.9993 & 0.30 & 0.99 \\
\hline Myricetin & 275 & 12.8 & $y=109.357 x+59.34$ & 0.9957 & 0.83 & 2.82 \\
\hline Gallic acid & 280 & 2.6 & $y=864.620 x-114.17$ & 0.9928 & 0.05 & 0.18 \\
\hline Ferulic acid & 320 & 6.4 & $y=640.052 x+88.14$ & 0.9991 & 0.12 & 0.39 \\
\hline Caffeic acid & 280 & 3.8 & $y=261.55 x+56.20$ & 0.9970 & 0.28 & 0.93 \\
\hline trans-Cinnamic acid & 280 & 4.7 & $y=173.062 x+44.91$ & 0.9994 & 0.58 & 1.91 \\
\hline p-coumaric acid & 320 & 11.1 & $y=243.526 x+84.28$ & 0.9961 & 0.34 & 1.13 \\
\hline
\end{tabular}

$R_{t}$ retention time, $y$ peak area, $x$ concentration of standard $\left(\mu \mathrm{g} \mathrm{mL}{ }^{-1}\right), R^{2}$ correlation coefficient for six data point in the calibration carve $(\mathrm{n}=3), L O D$ limit of detection LOQ limit of quantification

Table 5 Total phenolic content and some separated phenolic compounds from ethanol extract of $P$. speciosa seed collected from different locations of Malaysia

\begin{tabular}{|c|c|c|c|c|c|c|}
\hline Locations & Total phenolics & Gallic acid & Caffeic acid & Ferulic acid & trans-cinnamic acid & $\begin{array}{l}p \text {-coumaric } \\
\text { acid }\end{array}$ \\
\hline Perak & $26.3 \pm 2.74^{a}$ & $6.42 \pm 0.67^{\mathrm{a}}$ & $1.46 \pm 0.67^{a}$ & $2.71 \pm 0.89^{a}$ & $1.84 \pm 0.45^{a}$ & $2.73 \pm 0.41^{a}$ \\
\hline Negeri Sembilan & $20.5 \pm 2.26^{b}$ & $5.11 \pm 0.59^{b}$ & ND & $2.26 \pm 0.83^{a}$ & $1.05 \pm 0.29^{b}$ & $1.89 \pm 0.32^{b}$ \\
\hline Johor & $14.9 \pm 2.03^{c}$ & $3.56 \pm 0.28^{c}$ & $1.19 \pm 0.37^{\mathrm{a}}$ & ND & $0.64 \pm 0.04^{c}$ & ND \\
\hline
\end{tabular}

Data are means of triplicate measurements \pm standard deviation. Means not sharing a common single letter in each column for each measurement were significantly different at $\mathrm{P}<0.05$. The units of total phenolics and phenolic compounds aremg gallic acid equivalents per gram DM and mg per gram DM

ND not detected 
Table 6 DPPH and FRAP scavenging activities (at concentration of $100 \mu \mathrm{g} \mathrm{mL}^{-1}$ ) and IC ${ }_{50}$ value of ethanol extract of $P$. speciosa seed collected from different locations of Malaysia

\begin{tabular}{|c|c|c|c|c|}
\hline Locations & $\begin{array}{l}\text { DPPH free radical scavenging } \\
\text { activity (\%) }\end{array}$ & $I C_{50}\left(\mu \mathrm{g} \mathrm{mL}^{-1}\right)$ & $\begin{array}{l}\text { Ferric reducing antioxidant } \\
\text { potential ( } \mu \mathrm{M} \text { of } \mathrm{Fe}(\mathrm{II}) \mathrm{g}^{-1} \text { ) }\end{array}$ & $\mathrm{IC}_{50}\left(\mu \mathrm{g} \mathrm{mL}^{-1}\right)$ \\
\hline Perak & $66.29 \pm 4.88^{b}$ & $86.7 \pm 5.80^{c}$ & $522.1 \pm 18.29^{b}$ & $91.5 \pm 7.83^{c}$ \\
\hline Negeri Sembilan & $52.47 \pm 4.46^{c}$ & $109.2 \pm 6.12^{\mathrm{b}}$ & $462.5 \pm 14.80^{c}$ & $121.2 \pm 7.14^{b}$ \\
\hline Johor & $41.62 \pm 2.71^{d}$ & $153.1 \pm 6.32^{\mathrm{a}}$ & $407.5 \pm 11.62^{d}$ & $140.6 \pm 8.49^{a}$ \\
\hline \multicolumn{5}{|l|}{ Positive controls } \\
\hline a-tocopherol & $84.19 \pm 5.20^{\mathrm{a}}$ & $42.6 \pm 3.25^{\mathrm{e}}$ & $871.2 \pm 20.48^{\mathrm{a}}$ & $44.9 \pm 3.91^{e}$ \\
\hline $\mathrm{BHT}$ & $70.58 \pm 4.35^{b}$ & $79.6 \pm 4.04^{d}$ & $514.5 \pm 15.20^{b}$ & $93.5 \pm 4.37^{c}$ \\
\hline
\end{tabular}

Data are means of triplicate measurements \pm standard deviation. Means not sharing a common single letter in each column for each measurement were significantly different at $\mathrm{P}<0.05$

No represent not observed

influenced significantly by the sampling location. The highest activity was observed in the extract from the Perak site (66.29\%) followed by Negeri Sembilan (52.47\%) and Johor (41.62\%). DPPH activity of all extracts was lower than the positive standards ( $\alpha$-tocopherol $=84.19 \%$ and BHT $=70.58 \%)$. From the sampled sites, Perak exhibited lowest $\mathrm{IC}_{50}$ (the half-maximal inhibitory concentration) value $\left(86.7 \mu \mathrm{g} \mathrm{mL} \mathrm{m}^{-1}\right)$ and Johor exhibited highest $\mathrm{IC}_{50}$ content $\left(153.1 \mu \mathrm{g} \mathrm{mL} \mathrm{L}^{-1}\right)$. Lower $\mathrm{IC}_{50}$ values represent stronger free radical inhibition, as strong free-radical inhibitors are active at low concentrations. The ranking order of FRAP activity was as follows: Perak (522.1 $\mu \mathrm{M}$ of $\mathrm{Fe}(\mathrm{II}) \mathrm{g}^{-1}$ ), followed by Negeri Sembilan (462.5 $\mu \mathrm{M}$ of $\left.\mathrm{Fe}(\mathrm{II}) \mathrm{g}^{-1}\right)$, followed by Johor $(407.5 \mu \mathrm{M}$ of $\left.\mathrm{Fe}(\mathrm{II}) \mathrm{g}^{-1}\right)$. The lowest $\mathrm{IC}_{50}$ value was seen in the extracts from the Perak location $\left(91.5 \mu \mathrm{g} \mathrm{mL}^{-1}\right)$, followed by Negeri Sembilan $\left(121.2 \mu \mathrm{g} \mathrm{mL}^{-1}\right)$ and Johor $\left(140.6 \mu \mathrm{g} \mathrm{mL}^{-1}\right)$. $\alpha$-Tocopherol showed FRAP activity, which was higher than that of the P. speciosa seed extracts at all three locations. More interestingly, the FRAP activity of Perak extracts was higher than BHT, but no significant differences were observed between the extracts from the Perak location and BHT. Several studies reported that the antioxidant activity of herbs is significantly associated with their phytochemical content, especially that of flavonoids and phenolic acids [38-40]. In this study, the highest antioxidant activity as well as the highest content of flavonoids and phenolic acids was observed in P. speciosa seed extracts from the Perak location. Alternatively, variation in climatic conditions, soil nutrients, water quality (hydrogen potential, electrical conductivity), and agricultural activity could influence the production of phytochemicals, which in turn could affect the antioxidant activities.

\section{Antibacterial activity}

The antibacterial activity of $P$. speciosa seed extracts collected from different locations in Malaysia against both Gram-positive and Gram-negative bacteria is shown in Table 7 . The antibacterial activity was significantly influenced by the sampling location. Extracts from the Perak location had a strong inhibitory effect on all Gram-positive and Gram-negative bacterial strains tested, followed by extracts from Negeri Sembilan and Johor. Among the

Table 7 Antibacterial activity of ethanol extract of $P$. speciosa seed collected from different locations of Malaysia and antibiotics against bacterial strains

\begin{tabular}{|c|c|c|c|c|c|c|}
\hline \multirow[t]{2}{*}{ Bacterial strains } & \multicolumn{6}{|c|}{ Inhibition zone (mm) } \\
\hline & Perak & Negeri Sembilan & Johor & Gentamicin & Ciprofloxacin & DMSO: water (1:9 v/v) \\
\hline S. aureus & $7.2 \pm 0.346^{b}$ & $5.1 \pm 0.340^{c}$ & $5.0 \pm 0.462^{c}$ & $8.4 \pm 0.401^{\mathrm{a}}$ & $7.4 \pm 0.328^{b}$ & No \\
\hline B. subtilis & $8.4 \pm 0.320^{b}$ & $8.2 \pm 0.411^{b}$ & $6.2 \pm 0.140^{c}$ & $9.3 \pm 0.355^{\mathrm{a}}$ & $8.0 \pm 0.349^{b}$ & No \\
\hline L. monocytogenes & $2.0 \pm 0.151^{c}$ & No & No & $4.0 \pm 0.307^{b}$ & $4.5 \pm 0.279^{a}$ & No \\
\hline E. coli & $1.7 \pm 0.130^{c}$ & $1.2 \pm 0.153^{d}$ & $0.5 \pm 0.115^{\mathrm{e}}$ & $4.7 \pm 0.227^{\mathrm{a}}$ & $4.0 \pm 0.201^{b}$ & No \\
\hline S. typhimurium & $5.6 \pm 0.429^{c}$ & $4.1 \pm 0.208^{d}$ & $5.3 \pm 0.346^{c}$ & $6.8 \pm 0.430^{\mathrm{a}}$ & $6.0 \pm 0.490^{b}$ & No \\
\hline P. aeruginosa & $4.1 \pm 0.283^{b}$ & $2.8 \pm 0.116^{c}$ & No & $5.4 \pm 0.461^{a}$ & $5.1 \pm 0.406^{\mathrm{a}}$ & No \\
\hline
\end{tabular}

All analyses are the mean of triplicate measurements \pm standard deviation. Means not sharing a common letter in each row were significantly different at $\mathrm{P}<0.05$ No not observed 
bacterial strains used, Bacillus subtilis was the most sensitive to P. speciosa seed extracts. Extracts from Negeri Sembilan and Johor did not show antibacterial activity against Listeria monocytogenes. The Johor seed extracts also did not show antibacterial activity against Pseudomonas aeruginosa. Seed extracts from all three locations had a lower antibacterial effect than gentamicin and ciprofloxacin, which were used as positive controls. Generally, results showed that Gram-positive bacteria are more sensitive to $P$. speciosa extracts than Gram-negative bacteria. A recent study showed that the pod extract of $P$. speciosa also exhibits antibacterial activity against Bacillus cereus, L. monocytogenes, S. aureus, and Escherichia coli, with inhibition ranging 6.87 and $11.50 \mathrm{~mm}$ [41]. Gram-negative bacteria possess an outer membrane surrounding the cell wall, which restricts the diffusion of hydrophobic compounds through its lipopolysaccharide covering. Without an outer membrane, the extract is able to disrupt the cytoplasmic membrane, causing increased cell wall and cell membrane permeability. Moreover, it can disrupt the proton motive force, electron flow, active transport and coagulation of cell contents [42]. Our findings in this study are consistent with Musa et al. who reported that Gram-positive bacteria showed mostly sensitivity to $P$. speciosa extract, while Gram-negative bacteria were resistant to it [43]. The minimal inhibitory concentration (MIC) of seed extracts from the three different locations ranged between 40 and $100 \mu \mathrm{g} \mathrm{mL}$ (Table 8). A lower MIC value indicates stronger antibacterial activity, as strong bacterial inhibitors are active at low concentrations. Therefore, S. aureus was sensitive to seed extracts from Perak to Bacillus subtilis was sensitive to seed extracts from both Perak and Negeri Sembilan, with MIC of $40 \mu \mathrm{g} \mathrm{mL}{ }^{-1}$.

\section{Correlation analysis}

It is important to examine the correlations between the phytochemical content and the biological activity

Table 8 Minimal inhibitory concentration (MIC) of ethanol extract of $P$. speciosa seed collected from different locations against bacterial strains

\begin{tabular}{lcll}
\hline Bacterial strains & Perak & Negeri Sembilan & Johor \\
\hline S. aureus & 40.0 & 80.0 & 80.0 \\
B. subtilis & 40.0 & 40.0 & 60.0 \\
L. monocytogenes & $>100$ & No & No \\
E. coli & $>100$ & $>100$ & $>100$ \\
S. typhimurium & 80.0 & $>100$ & 80.0 \\
P. aeruginosa & 80.0 & $>100$ & No \\
\hline
\end{tabular}

All analyses are the mean of triplicate measurements \pm standard deviation; unit is $\mu \mathrm{g} \mathrm{mL}^{-1}$

No not observed of crops or herbs in order to identify the compounds responsible for the biological activity of each plant. This knowledge could help researchers to establish the most suitable growth conditions and the best harvesting and extraction techniques in order to maximize the production of the compounds of interest. In this study, correlation analysis between identified phytochemicals and biological activities of $P$. speciosa seed was examined (Table 9). The DPPH activity of P. speciosa seed extracts was found to be significantly correlated with flavonoid and phenolic acid content, with the exception of caffeic acid $\left(R^{2}=0.525\right)$ and $p$-coumaric acid $\left(R^{2}=0.619\right)$. The highest correlation was seen between DPPH activity and TFC $\left(R^{2}=0.941\right)$. In the FRAP analysis, FRAP activity also correlated significantly with flavonoid and phenolic acid content, with the exceptions of ferulic acid, caffeic acid and $p$-coumaric acid. The highest correlation was seen between FRAP activity and TFC $\left(R^{2}=0.966\right)$. Antibacterial activity also correlated significantly with flavonoids and phenolic acids, except rutin, caffeic acid, and $p$-coumaric acid. The highest correlation was seen between antibacterial activity and TPC $\left(R^{2}=0.933\right)$. Our findings in current study are consistent with those of previous studies, which have shown positive and significant correlations between flavonoid and phenolic acid levels and the biological activity in herbs and crops $[39,40,44]$. The chemical diversity of plants is more complex than any chemical library made by humans, and the plant kingdom therefore represents an enormous reservoir of valuable molecules just waiting to be discovered.

Table 9 Correlation analysis between identified phytochemicals and biological activities of $P$. speciosa seed

\begin{tabular}{lccc}
\hline Phytochemicals & DPPH activity & FRAP activity & $\begin{array}{l}\text { Antibacterial } \\
\text { activity }\end{array}$ \\
\hline TFC & $0.941^{* *}$ & $0.966^{* *}$ & $0.906^{* *}$ \\
TPC & $0.883^{* *}$ & $0.860^{* *}$ & $0.933^{* *}$ \\
Quercetin & $0.911^{* *}$ & $0.894^{* *}$ & $0.917^{* *}$ \\
Rutin & $0.728^{*}$ & $0.741^{*}$ & $0.611^{\text {n.s }}$ \\
Kaempferol & $0.930^{* *}$ & $0.862^{* *}$ & $0.889^{* *}$ \\
Catechin & $0.886^{* *}$ & $0.841^{* *}$ & $0.847^{* *}$ \\
Luteolin & $0.886^{* *}$ & $0.900^{* *}$ & $0.895^{* *}$ \\
Myricetin & $0.820^{* *}$ & $0.871^{* *}$ & $0.755^{*}$ \\
Gallic acid & $0.900^{* *}$ & $0.844^{* *}$ & $0.921^{* *}$ \\
Ferulic cid & $0.749^{*}$ & $0.669^{\text {n.s }}$ & $0.882^{* *}$ \\
Caffeic acid & $0.525^{\text {n.s }}$ & $0.627^{\mathrm{n.s}}$ & $0.600^{\mathrm{n} . \mathrm{s}}$ \\
trans-Cinnamic acid & $0.861^{* *}$ & $0.794^{*}$ & $0.781^{*}$ \\
p-coumaric acid & $0.619^{\mathrm{n} . \mathrm{s}}$ & $0.406^{\mathrm{n} . \mathrm{s}}$ & $0.473^{\mathrm{n} . \mathrm{s}}$ \\
\hline
\end{tabular}

n.s, ${ }^{*}$ and ${ }^{* *}$ represent non-significant, significant at $\mathrm{p}<0.05$ and $\mathrm{p}<0.01$, respectively 


\section{Conclusion}

The results of this study indicate that the phytochemical composition and the biological activity of $P$. speciosa seeds vary significantly depending on where in Malaysia it is grown. P. speciosa grown in the Perak displayed the highest phytochemical content, antioxidant and antibacterial activities. They were followed by the Negeri Sembilan and Johor regions. The extracts contained substantial amounts of quercetin, kaempferol, and gallic acid, all of which potently inhibited the growth of Gram-positive and Gram-negative bacteria. The biological activity of $P$. speciosa seed extracts significantly correlated with their flavonoid content, followed by the phenolic acid content. The results of this study strongly suggest using the Perak location for plantation and sampling of $P$. speciosa and for further investigation.

\section{Abbreviations}

DMSO: dimethyl sulfoxide; DPPH: 2,2-diphenyl-1-picrylhydrazyl; $\mid \mathrm{C}_{50}$ : halfmaximal inhibitory concentration; MTT: (3-(4,5-dimethylthiazol-2-yl)-2,5-diphenyltetrazolium bromide); TFC: total flavonoid content; TPC: total phenolic content; UHPLC: ultra-high performance liquid chromatography.

\section{Authors' contributions}

AG and HZEJ did study design, phytochemical analysis and antioxidant activities. MFMB and MHR carried out phytochemical extraction. AR participated in antimicrobial analysis. The first draft of the paper was written by AG and reviewed by all authors. All authors read and approved the final manuscript.

\section{Author details}

${ }^{1}$ Department of Crop Science, Faculty of Agriculture, Universiti Putra Malaysia, 43400 Serdang, Selangor, Malaysia. ${ }^{2}$ Department of Biology, Universiti Malaysia Sarawak, 94300 Samarahan, Sarawak, Malaysia. ${ }^{3}$ Department of Nutrition \& Dietetics, Faculty of Medicine \& Health Sciences, Universiti Putra Malaysia, 43400 Serdang, Selangor, Malaysia.

\section{Acknowledgements}

The authors are grateful to the Research Management Centre of Universiti Putra Malaysia. The authors would like to acknowledge from all staff of laboratory of nutrition, department of nutrition and dietetics, faculty of medicine and health sciences, Universiti Putra Malaysia for all the helps and guidance in order to accomplish this project.

\section{Ethics approval and consent to participate}

Not applicable.

\section{Competing interests}

The authors declare that they have no competing interests.

\section{Availability of data and materials}

We have presented all our main data in the form of tables. The data sets supporting the conclusions of this article are included within the article.

\section{Funding}

Financial support for this study was given by Ministry of Agriculture and Agrobased Industry (MOA), project NKEA-EPP1 (Malaysian herbal monograph), Malaysia. The funding source had no involvement in the study.

\section{Publisher's Note}

Springer Nature remains neutral with regard to jurisdictional claims in published maps and institutional affiliations.
Received: 9 January 2017 Accepted: 20 January 2018

Published online: 07 February 2018

\section{References}

1. Simazaki D, Kubota R, Suzuki T, Akiba M, Nishimura T, Kunikane S (2015) Occurrence of selected pharmaceuticals at drinking water purification plants in Japan and implications for human health. Water Res 76:187-200

2. Bagetta G, Cosentino M, Corasaniti MT, Sakurada S (2016) Herbal medicines: development and validation of plant-derived medicines for human health. CRC Press, Boca Raton

3. Cseke LJ, Kirakosyan A, Kaufman PB, Warber S, Duke JA, Brielmann HL (2016) Natural products from plants. CRC Press, Boca Raton

4. Nigg HN, Seigler D (2013) Phytochemical resources for medicine and agriculture. Springer Science \& Business Media, Berlin

5. Tiwari BK, Brunton NP, Brennan C (2013) Handbook of plant food phytochemicals: Sources, stability and extraction. Wiley, Hoboken

6. Stuart G (2010) Philippine alternative medicine. In: Manual of some Philippine medicinal plants

7. Orwa C, Mutua A, Kindt R, Jamnadass R, Anthony S (2009) Agroforestry tree database: a tree reference and selection guide version 4.0

8. Reihani S, Azhar M (2012) Antioxidant activity and total phenolic content in aqueous extracts of selected traditional Malay salads (Ulam). Int Food Res J 19(4):1439-1444

9. Maisuthisakul P, Pasuk S, Ritthiruangdej P (2008) Relationship between antioxidant properties and chemical composition of some Thai plants. J Food Compos Anal 21(3):229-240

10. Gmelin R, Susilo R, Fenwick G (1981) Cyclic polysulphides from Parkia speciosa. Phytochemistry 20(11):2521-2523

11. Jamaluddin F, Mohamed S, Lajis MN (1994) Hypoglycaemic effect of Parkia speciosa seeds due to the synergistic action of $\beta$-sitosterol and stigmasterol. Food Chem 49(4):339-345

12. Ali $H$, Houghton $P$, Soumyanath $A$ (2006) a-amylase inhibitory activity of some Malaysian plants used to treat diabetes; with particular reference to Phyllanthus amarus. J Ethnopharmacol 107(3):449-455

13. Aisha A, Abu-Salah KM, Alrokayan SA, Ismail Z, Abdulmajid A (2012) Evaluation of antiangiogenic and antioxidant properties of Parkia speciosa Hassk extracts. Pak J Pharm Sci 25:7-14

14. Sakunpak A, Panichayupakaranant P (2012) Antibacterial activity of Thai edible plants against gastrointestinal pathogenic bacteria and isolation of a new broad spectrum antibacterial polyisoprenylated benzophenone, chamuangone. Food Chem 130(4):826-831

15. Bian ZH, Yang QC, Liu WK (2015) Effects of light quality on the accumulation of phytochemicals in vegetables produced in controlled environments: a review. J Sci Food Agric 95(5):869-877

16. Ghasemzadeh A, Jaafar HZ, Rahmat A, Devarajan T (2014) Evaluation of bioactive compounds, pharmaceutical quality, and anticancer activity of curry leaf (Murraya koenigii L.). Evid Based Complement Alternat Med. https://doi.org/10.1155/2014/873803

17. Tiwari U, Cummins E (2013) Factors influencing levels of phytochemicals in selected fruit and vegetables during pre- and post-harvest food processing operations. Food Res Int 50(2):497-506

18. Ghasemzadeh A, Jaafar HZ (2013) Profiling of phenolic compounds and their antioxidant and anticancer activities in pandan (Pandanus amaryllifolius Roxb.) extracts from different locations of Malaysia. BMC Complement Altern Med 13(1):1

19. Ayoola G, Coker H, Adesegun S, Adepoju-Bello A, Obaweya K, Ezennia E, Atangbayila T (2008) Phytochemical screening and antioxidant activities of some selected medicinal plants used for malaria therapy in southwestern Nigeria. Trop J Pharm Res 7(3):1019-1024

20. Iqbal E, Salim KA, Lim LB (2015) Phytochemical screening, total phenolics and antioxidant activities of bark and leaf extracts of Goniothalamus velutinus (Airy Shaw) from Brunei Darussalam. J King Saud Univ Sci 27(3):224-232

21. Kerian K (2012) Phytochemicals screening and total phenolic content of Malaysian Zea mays hair extracts 
22. Pothitirat W, Chomnawang MT, Supabphol R, Gritsanapan W (2009) Comparison of bioactive compounds content, free radical scavenging and anti-acne inducing bacteria activities of extracts from the mangosteen fruit rind at two stages of maturity. Fitoterapia 80(7):442-447

23. Vongsak B, Sithisarn P, Mangmool S, Thongpraditchote S, Wongkrajang Y, Gritsanapan W (2013) Maximizing total phenolics, total flavonoids contents and antioxidant activity of Moringa oleifera leaf extract by the appropriate extraction method. Ind Crops Prod 44:566-571

24. Jayaprakasha G, Patil BS (2007) In vitro evaluation of the antioxidant activities in fruit extracts from citron and blood orange. Food Chem 101(1):410-418

25. Dudonné S, Vitrac X, Coutiere P, Woillez M, Mérillon J-M (2009) Comparative study of antioxidant properties and total phenolic content of 30 plant extracts of industrial interest using DPPH, ABTS, FRAP, SOD, and ORAC assays. J Agri Food Chem 57(5):1768-1774

26. Kamisah Y, Othman F, Qodriyah HMS, Jaarin K (2013) Parkia speciosa hassk:: a potential phytomedicine. Evid Based Complement Alternat Med

27. Ghasemzadeh A, Jaafar HZ, Karimi E, Ibrahim MH (2012) Combined effect of CO 2 enrichment and foliar application of salicylic acid on the production and antioxidant activities of anthocyanin, flavonoids and isoflavonoids from ginger. BMC Complement Alternat Med 12(1):1

28. Ghasemzadeh A, Jaafar $\mathrm{HZ}$ (2011) Effect of $\mathrm{CO}_{2}$ enrichment on synthesis of some primary and secondary metabolites in ginger (Zingiber officinale Roscoe). Int J Mol Sci 12(2):1101-1114

29. Karimi E, Jaafar HZ, Ghasemzadeh A, Ibrahim MH (2013) Light intensity effects on production and antioxidant activity of flavonoids and phenolic compounds in leaves, stems and roots of three varieties of Labisia pumila Benth. Aust J Crop Sci 7(7):1016

30. Ghasemzadeh A, Ghasemzadeh N (2011) Effects of shading on synthesis and accumulation of polyphenolic compounds in ginger (Zingiber officinale Roscoe) varieties. J Med Plant Res 5(11):2435-2441

31. Ghasemzadeh A, Ashkani S, Baghdadi A, Pazoki A, Jaafar HZ, Rahmat A (2016) Improvement in flavonoids and phenolic acids production and pharmaceutical quality of sweet basil (Ocimum Basilicum L.) by Ultraviolet-B Irradiation. Molecules 21(9):1203

32. Zarrouk O, Francisco R, Pinto-Marijuan M, Brossa R, Santos RR, Pinheiro C, Costa JM, Lopes C, Chaves MM (2012) Impact of irrigation regime on berry development and flavonoids composition in Aragonez (Syn. Tempranillo) grapevine. Agric Water Manag 114:18-29
33. Yang Y, Xue S, Wang Y, Li Y (2003) The influence of humic acid fertilizer on the content of the flavonoids in the ginkgo biloba leaf. J Hebei Agri Univ 27(6):22-25

34. Omar NF, Hassan SA, Yusoff UK, Abdullah NAP, Wahab PEM, Sinniah UR (2012) Phenolics, flavonoids, antioxidant activity and cyanogenic glycosides of organic and mineral-base fertilized cassava tubers. Molecules 17(3):2378-2387

35. Wang SY, Zheng W (2001) Effect of plant growth temperature on antioxidant capacity in strawberry. J Agri Food Chem 49(10):4977-4982

36. Gliszczyńska-Świgło A, Kałużewicz A, Lemańska K, Knaflewski M, Tyrakowska B (2007) The effect of solar radiation on the flavonol content in broccoli inflorescence. Food Chem 100(1):241-245

37. Patil B, Pike L, Hamilton B (1995) Changes in quercetin concentration in onion (Allium cepa L.) owing to location, growth stage and soil type. New Phytol 130(3):349-355

38. Wojdyło A, Oszmiański J, Czemerys R (2007) Antioxidant activity and phenolic compounds in 32 selected herbs. Food Chem 105(3):940-949

39. Nile SH, Park SW (2014) Edible berries: bioactive components and their effect on human health. Nutrition 30(2):134-144

40. Heim KE, Tagliaferro AR, Bobilya DJ (2002) Flavonoid antioxidants: chemistry, metabolism and structure-activity relationships. J Nutr Biochem 13(10):572-584

41. Wonghirundecha S, Benjakul S, Sumpavapol P (2014) Total phenolic content, antioxidant and antimicrobial activities of stink bean (Parkia speciosa Hassk.) pod extracts. Songklanakarin. J Sci Technol 36:301-308

42. Sánchez E, García S, Heredia N (2010) Extracts of edible and medicinal plants damage membranes of Vibrio cholerae. Appl Environ Microbiol 76(20):6888-6894

43. Musa N, Wei LS, Seng CT, Wee W, Leong LK (2008) Potential of edible plants as remedies of systemic bacterial disease infection in cultured fish. Glob J Pharmacol 2(2):31-36

44. Ghasemzadeh A, Talei D, Jaafar HZ, Juraimi AS, Mohamed MTM, Puteh A, Halim MRA (2016) Plant-growth regulators alter phytochemical constituents and pharmaceutical quality in Sweet potato (Ipomoea batatas L.) BMC Complement Alternat Med 16(1):1

\section{Submit your manuscript to a SpringerOpen ${ }^{\circ}$ journal and benefit from:}

- Convenient online submission

- Rigorous peer review

- Open access: articles freely available online

- High visibility within the field

- Retaining the copyright to your article

Submit your next manuscript at $\boldsymbol{\nabla}$ springeropen.com 